his friends, colleagues, students, and strangers.

His brilliant and productive career as a political scientist both drew upon and reinvigorated his personal and political commitment to preserving and enhancing all human life. $\mathrm{He}$ was a man as good and kindly as his scholarship was great.

He received strength from his many friends and most of all from his family. He is survived by his wife, Juanita, and their children, Marit, Mia and Helge. His presence is deeply missed.

Joseph Fletcher

Alkis Kontos

University of Toronto

\section{Guy Renfro Donnell}

Guy R. Donnell, Oklahoma State University emeritus professor of political science, 86 , died on November 2 . For 25 years he taught politics to students enthralled by his quick wit and carefree cynicism. Students flocked to enroll in his classes, and when the time finally came for him to retire in 1970 , he was honored with a scholarship fund from which awards are granted annually in his memory.

With Guy Donnell's passing, another gallant witness to pioneer times in the Southwest is gone. His mother, Iva May, came to Texas with her parents after a nine-week trip by covered wagon from Illinois. She married John Donnell, whose father had fought with the Mississippi Regiment in the Civil War. She strongly encouraged their three children to excel in school, and between them they went on to earn seven university degrees. When Guy Donnell graduated from Saint Jo High School, Montague County, he was the valedictorian of his class. He studied for one year at what was then called North Texas State Teachers College in Denton, after which, at the ripe age of 18 , he secured the first of several teaching jobs in small county schools. Living frugally, he managed to squeeze in semesters at college between teaching jobs. It took him nine years to get his bachelors degree, which was awarded by the University of Oklahoma, and several more years to get master's and doctoral degrees from the University of Texas in Austin.

When World War II broke out, Donnell joined the U.S. Army Air Corps. He served as a flight commander at the Aviation Cadet Center in San Antonio, which was then regarded as the elite school for army aviators. Donnell abhorred pomp and pretentiousness. He had a reputation for being kind and considerate to cadets, who were often the butt of harsh discipline administered by younger officers with heads freshly swelled at West Point. Thanks to friendships formed in those days, Donnell received shortly after the war a welcome invitation to join the political science faculty at Oklahoma A\&M in Stillwater.

Donnell became a mainstay of the political science department, which he managed almost single-handedly while the nominal head of the department busied himself with more lucrative ventures. Donnell planned the class schedules, attended countless committee meetings, advised hundreds of students, and taught three or four courses a semester, all the time delighting students with wicked anecdotes and sarcasms he found it inadvisable to repeat outside of the classroom. His familiarity with state and local politics affected both his view of human nature and his view of academic political science. He would often merrily dismiss a piece of scholarly writing by comparing its author's intelligence unfavorably to that of his cat, Cochise.

Donnell was a great favorite of faculty members of all departments. His election to serve on the university's Faculty Council testified to their respect for him. He himself took special pride, however, in his service on the university's Athletic Cabinet, appointment to which, as the only university committee from which faculty members drew any tangible benefits, was incontrovertible proof he was not a chump.

After his retirement from the OSU faculty Donnell continued to frequent the campus and to regale friends and colleagues with amusing stories and outrageous insights. Even as he coped valiantly with the loss of his wife, Sue, and three serious illnesses, his intelligence and sense of humor never faltered. Vigorous and charming into his ninth decade, he found a new and valued friend, Mary Elizabeth Jones, who joined him in marriage and brought him new happiness.

Bertil Hanson

Oklahoma State University

\section{Cecelia Kenyon}

Cecelia Marie Kenyon (Cele as she was more generally known) died in her home in Northampton on January 22, 1990. She was born in Gainesville, Georgia, in 1922, and received her $\mathrm{Ph} . \mathrm{D}$. from Radcliffe in 1949. She had come to Smith the year before as an instructor and remained a member of the Smith faculty until she retired in 1984 . She was named the Charles N. Clark Professor of Government in 1969.

Her field was European and American political theory, and most of her scholarly writing dealt with the political theoretical arguments surrounding the birth of the American Republic. For a variety of reasons she did not publish much, but the articles and books she did publish have become classics in her field to be cited, discussed, and argued about by others. This is especially true of her seminal essay, "Men of Little Faith: The AntiFederalists on the Nature of Representative Government," which was originally published in 1955 and then, expanded to over 100 pages, served as an introductory essay to her edited volume The Anti-Federalists, published in 1966.

In recognition of her contribution to our understanding of the foundations of the American political order, Cele was awarded an honorary degree by Rutgers University in 1976. In the same year, she spoke before the U.S. Congress at a program marking the birthday of Thomas Jefferson, one of her heroes. Two years earlier, in 1974, she had been chosen to address the United States House of Representatives at a program marking the 200th anniversary of the First Continental Congress. She also served as a member of the Board of Trustees of Oberlin College, where she had received her B.A. degree.

If Cele was a creative scholar, she was also a respected and revered 